\title{
Elimination of Grapevine leafroll associated virus-3, Grapevine rupestris stem pitting associated virus and Grapevine virus $A$ from a Tunisian Cultivar by So- matic Embryogenesis and Characterization of the Somaclones Using Ampelo- graphic Descriptors
}

\author{
Badra Bouamama-Gzara ${ }^{1 *}$, Ilhem Selmi ${ }^{2}$, Samir Chebil ${ }^{1}$, Imene Melki ${ }^{1}$, Ahmed Mliki ${ }^{1}$, Abdelwahed Ghorbel, \\ Angela Carra ${ }^{3}$, Francesco Carimi ${ }^{3}$, and Naima Mahfoudhi ${ }^{2}$ \\ ${ }^{I}$ Center of Biotechnology of Borj-Cédria. Laboratory of Plant Molecular Physiology, BP. 901, Hammam-Lif, 2050. Tunisia \\ ${ }^{2}$ Institut National de Recherche Agronomique de Tunisie, Laboratoire de Protection des Végétaux. Rue Hedi Karray, El \\ Menzah, 1004, Tunisie \\ ${ }^{3}$ Consiglio Nazionale delle Ricerche UOS di Palermo, Instituto di Bioscienze e BioRisorse, Corso Calatafimi, 414, Pal- \\ ermo, 90129, Italy
}

(Received on June 13, 2017; Revised on August 28, 2017; Accepted on August 29, 2017)

Prospecting of local grapevine (Vitis vinifera L.) germplasm revealed that Tunisia possesses a rich patrimony which presents diversified organoleptic characteristics. However, viral diseases seriously affect all local grapevine cultivars which risk a complete extinction. Sanitation programs need to be established to preserve and exploit, as a gene pool, the Tunisian vineyards areas. The presence of the Grapevine leafroll associated virus-3 (GLRaV-3), Grapevine stem pitting associated virus (GRSPaV) and Grapevine virus $A$ (GVA), were confirmed in a Tunisian grapevine cultivar using serological and molecular analyses. The association between GRSPaV and GVA viruses induces more rugose wood symptoms and damages. For this reason the cleansing of the infected cultivar is highly advisable. Direct and recurrent somatic embryos of cv. 'Hencha' were successfully induced from filament, when cultured on Chée and Pool (1987). based-medium, enriched with $2 \mathrm{mg}^{-1}$ of 2,4-dichlorophenoxyacetic acid and $2.5 \mathrm{mg}$ $1^{-1}$ of Thidiazuron, after 36 weeks of culture. After six months of acclimatization, RT-PCR carried on $\mathbf{5 0}$

\footnotetext{
*Corresponding author.

Phone) 0021679325 511, FAX) 0021679325638

E-mail)badrabouamama@yahoo.com

(c) This is an Open Access article distributed under the terms of the Creative Commons Attribution Non-Commercial License (http:// creativecommons.org/licenses/by-nc/4.0) which permits unrestricted noncommercial use, distribution, and reproduction in any medium, provided the original work is properly cited.
}

Articles can be freely viewed online at www.ppjonline.org. somaplants confirmed the absence of GVA, GRSPa$\mathrm{V}$ as well as GLRaV-3 viruses in all somaplants. Ampelographic analysis, based on eight OIV descriptors, was carried out on two years acclimated somaplants, compared to the mother plant. Results demonstrated that the shape and contours of 46 somaclones leaves are identical to mother plant leaves and four phenotypically off-type plants were observed. The healthy state of $100 \%$ 'Hencha' somaclones and the high percentage of phenotypically true-to-type plants demonstrate that somatic embryogenesis is a promising technique to adopt for grapevine viruses elimination.

Keywords : ELISA, OIV descriptors, RT-PCR, somatic embryos, virus elimination

Handling Associate Editor : Ju, Ho-Jong

With an annual production of over 77 million tons (OIV, 2016), grapevine is one of the most important fruit crops in the world, with a cultivated area exceeding 75 million ha. However, grapevine is subject to several attacks by numerous pests and pathogens, including graft-transmissible agents such as viruses, viroids, and phytoplasmas among which infectious intracellular agents play a major role, causing heavy losses in yield and fruit quality, shortening the productive life of vineyards and endangering the survival itself of affected vines. Grapevine viruses have been associated with a reduction in vine growth and loss in canes 
pruning weight, graft incompatibility, vine decline and death (Santini et al., 2009; Uyemoto and Rowhani, 2003).

Grapevine supports a particular range of infectious agents. In fact, more than 60 different virus species have been documented in this crop (Martelli, 2009). On a worldwide basis, more viruses have been identified in grapevines than in any other woody perennial crop, taking in consideration that viruses are disseminated mainly through vegetative propagation and grafting (Waite et al., 2015). All currently documented grapevine viruses are classified into four major groups based on the disease they cause or are associated with: viruses involved in the degeneration/decline disease complex (Martelli, 2014), viruses associated with the leafroll disease complex (Gugerli, 2003), viruses associated with the rugose wood complex (Saldarelli, 2012), and viruses associated with the fleck disease complex (Martelli et al., 2002). Those viruses are characterized by numerous symptoms, such as stunting, reduced vigor, malformations of the leaves and twigs, foliar discolorations, grooving and/ or pitting of the woody cylinder (Martelli, 2014). Further discoveries of un-described viral pathogens are currently provided using new molecular techniques such as the next generation sequencing (NGS) as described by Al Rwahnih et al (2015).

Climatic variable and landforms offer very convenient conditions for grape growing in Tunisia. Actually, Tunisia possesses a rich autochthonous wild and cultivated grapevines patrimony which gathers around 70 distinct genotypes between native varieties and accessions (Zoghlami et al., 2001, 2009). Despite the sharp reduction in the viticulture area from 57,000 ha to 29,000 ha following the colonialism, grapevine still remains an important fruit crop in Tunisia (OIV, 2016). Recently, sanitary status of Tunisian grapevine has been explored to know the incidence of grapevine viruses and to preserve, on the other hand, the genetic resources by taking the appropriate sanitary measures. In fact, survey on health status of cultivated grapevine was carried out; Mahfoudhi et al. (1998, 2007, $2008,2014 b$ ) reported that each local cultivar was at least infected by two to three viruses. The presence of the most important grapevine viruses associated to grapevine leafroll disease, rugose wood disease and fanleaf degeneration in Tunisian vineyards was confirmed (Mahfoudhi et al., 2007, 2014a, 2014b). In such situation, certification of planting material under state control is needed. Therefore, the use of virus-free grapevine for multiplication and vineyard planting is extremely desirable. As indicated by Martelli (2014), the production of virus-free grapevine plants can be obtained following the clonal and sanitary selection scheme. This program must include a sanitation phase for those selected and infected candidates.

Actually, sanitation programs of grapevines are being complemented with the development of in vitro regeneration systems. A report on successful virus elimination from infected plants, through the use of somatic embryogenesis, has been published. In fact, somatic embryogenesis was effective in eliminating Grapevine fanleaf virus and Grapevine leafroll-associated viruses using grapevines anthers culture (Goussard et al., 1991). Later, Goussard and Wiid (1992) combined somatic embryogenesis and thermotherapy for Grapevine fanleaf virus elimination. This technique was successfully used for the elimination of Grapevine rupestris stem pitting associated virus (Gribaudo et al., 2006). Considering the sanitary status of the Tunisian grapevine, as well as the importance of producing virusfree plants, direct somatic embryos derived from stamen cultures will be used as an in vitro regeneration system to eliminate mixed grapevine virus infections from $\mathrm{cv}$. 'Hencha', a native grapevine cultivar originated from the south region of Tunisia and preserved in the Center of Biotechnology of Borj-Cédria collection (CBBC). The genetic fidelity of regenerated plants will be evaluated by ampelographic analysis using some foliar OIV descriptors (OIV, 2007).

\section{Materials and Methods}

Somatic embryogenesis procedure. Somatic embryogenesis was carried out using stamen from cv. 'Hencha'. Immature inflorescences, collected at stage $\mathrm{H}$ of Baggiolini (1952), were surface sterilized under aseptic conditions with ethanol $70 \%$ for $1 \mathrm{~min}$, followed by distilled water rinsing, and then they were immersed, for $20 \mathrm{~min}$, in a sodium hypochlorite solution $\left(12^{\circ}\right) \mathrm{NaOCl}$ at $6 \%$. The inflorescences were thoroughly rinsed five times with autoclaved distilled water. After removing flowers capuchin, stamens were plated on $9 \mathrm{~cm}$ Petri dishes containing modified Chée and Pool (1987) based-medium (CP), supplemented with $150 \mathrm{mg}^{-1}$ myo-inositol, $100 \mathrm{mg}^{-1}$ Fe-EDTA, $200 \mathrm{mg}$ $\mathrm{l}^{-1}$ glutamine, $30 \mathrm{~g} \mathrm{l}^{-1}$ sucrose and solidified with $3 \mathrm{~g} \mathrm{l}^{-1}$ Gelrite. The CP based medium was enriched with $2 \mathrm{mg}$ $\mathrm{l}^{-1}$ 2,4-dichlorophenoxyacetic acid (2,4-D) and $2.5 \mathrm{mg} \mathrm{l}^{-1}$ of N-Phenyl-N'-(1,2,3-thiadiazol-5-yl) urea (Thidiazuron, TDZ) (Bouamama et al., 2007). The cultures were incubated in a culture room at $24 \pm 1^{\circ} \mathrm{C}$ in a 16-hour light at an intensity of $100 \mu \mathrm{E} \mathrm{m}^{-2} \mathrm{~s}^{-1}$.

For germination, mature somatic embryos were transferred to MS (Murashige and Skoog, 1962) basal-medium without plant growth regulators. Germinated somatic embryos were placed in rooting MS basal-medium contain- 
ing $0.5 \mathrm{mg}^{-1}$ active charcoal and maintained for 6 weeks under the same culture conditions described above. All the media were adjusted to $\mathrm{pH} 5.8$ prior to addition of gelrite and autoclaved at $+115^{\circ} \mathrm{C}$ for 24 min. Finally, regenerated somaplantlets with well-developed root system were subsequently transferred in pots containing autoclaved peat and they were conserved in a phytotron chamber culture till 6 months. Somaplants of about $50 \mathrm{~cm}$ length, and containing an average of 50 leaves per plant, were transferred in an insect proof.

The morphology of regenerants was monitored during the developmental stages of somatic embryogenesis (proembryos, globular, heart, torpedo and cotyledonary-like structures). Photos were taken using a stereoscopic microscope (Newport, line tool company. Cedar Crest, NM. 87008 USA) and a digital camera (japan).

Environmental scanning electron microscopy (ESEM). Samples of somatic embryos $(0.5 \mathrm{~cm}$ diameter $)$ were mounted on aluminum stubs with double sided adhesive tape and directly observed using an ESEM (Fei company, Oregon, USA), suitable for biological material observation, without prior chemical fixation. Secondary electron images were taken at an accelerating voltage of 10 to $15 \mathrm{kV}$ and a vapor pressure of 0.7-0.8 Torr (Bouamama et al., 2011).

Ampelographic analysis. Eight ampelographic descriptors ([O-016, U-16], [O-017, U-17], [O-051, U-7], [O-053, U-8], [O-067, U-20], [O-68, U-21], [O-076, U-26], [O079, U-27]) assumed by the Organisation Internationale de la Vigne et du Vin (OIV, 2007) were evaluated to discern grapevine somaclones by phenotypic features. Analyses were performed by two observers, 30 months after acclimatization, on three random replicates for each candidate somaclone grown in an insect proof screen house.

Serological assays. Mature canes of 'Hencha mother plant were tested by DAS-ELISA using specific antibodies to Grapevine leafroll associated virus 1, 2 and 3 (GLRaV-1, GLRaV-2, GLRaV-3), Grapevine fanleaf virus (GFLV), Arabis mosaic virus (ArMV) and Grapevine virus A (GVA), and TAS-ELISA using specific antibodies to Grapevine fleck virus (GFkV) (Agritest, Bari, Italy), according to manufacturer's instructions. Extracts were obtained from cold-stored mature canes by macerating cortical scrapings in a mortar in the presence of PBS-buffer. Absorbance was recorded at $405 \mathrm{~nm}$ using an automatic microplate reader (Multiskan Ascent, Labsystems, Waltham, MA, USA).

Molecular analysis. To confirm, in one hand, the presence of viruses detected by ELISA and to detect other viruses in cv. 'Hencha' mother plant, molecular analyses was performed using specific primers to Grapevine leafroll associated virus 3, Grapevine virus A, Grapevine virus D and Grapevine rupestris stem pitting associated virus that amplify sequences of "546, 236, 474 and 329 bp" respectively (Table 1). On the hand, to verify the sanitary state of 50 somaplantlets, 6 months after acclimatization, molecular analysis were carried out for the detection of the viruses present in the mother plant. TNA extraction, cDNA synthesis and PCR amplification were performed in the same way as for the analyses of the mother plant.

Total nucleic acids (TNAs) were extracted from $0.2 \mathrm{~g}$ of phloem tissues (cortical scrapings), homogenized in 1 $\mathrm{ml}$ grinding buffer $(0.4 \mathrm{M}$ guanidine thiocyanate, $0.2 \mathrm{M}$ $\mathrm{NaOAc}$ pH 5.2, 25 mM EDTA, 1.0 M KOAc pH 5.0 and $2.5 \% \mathrm{w} / \mathrm{v}$ PVP-40) and purified according to Foissac et al (2001).

A two-step protocol was used for the reverse transcription (RT) and amplification (PCR) of target RNA. Reverse transcription was performed using $1 \mu \mathrm{l}$ of Moloney murine leukaemia virus reverse transcriptase (M-MLV 200 units/ $\mu \mathrm{l}), 4 \mu \mathrm{l}$ of $5 \times$ Fs M-MLV buffer, $2 \mu \mathrm{l}$ of DTT $(0.1 \mathrm{M})$ and $0.5 \mu \mathrm{l}$ of dNTPs $(10 \mathrm{mM})$. The mixture was incubated at

Table 1. Specific primers used for the detection of GVA, GVD, GRSPaV and GLRaV-3 in 'Hencha' mother plant as well as in regenerated somaplantlets

\begin{tabular}{|c|c|c|c|c|}
\hline Viruses & Primers & Sequences & Products (bp) & References \\
\hline GVA & $\begin{array}{l}\mathrm{H} 7038 \\
\mathrm{C} 7273\end{array}$ & $\begin{array}{l}\text { AGGTCCACGTTTGCTAAG } \\
\text { CATCGTCTGAGGTTTCTACTAT }\end{array}$ & $236 \mathrm{bp}$ & Mackenzie (1997) \\
\hline GLRaV-3 & $\begin{array}{l}\text { LR3-LC1F } \\
\text { LR3-LC2R }\end{array}$ & $\begin{array}{l}\text { CGC TAG GGC TGT GGA AGT ATT } \\
\text { GTT GTC CCG GGT ACC AGA TAT }\end{array}$ & $546 \mathrm{bp}$ & Ling et al. (1998) \\
\hline GRSPaV & $\begin{array}{l}\text { RS-H48 } \\
\text { RSP-C49 }\end{array}$ & $\begin{array}{l}\text { AGCTGGGATTATAAGGGAGGT } \\
\text { CCAGCCGTTCCACCACTAAT }\end{array}$ & $329 \mathrm{bp}$ & Lima et al. (2006) \\
\hline GVD & $\begin{array}{l}\text { CP7V } \\
\text { CP471C }\end{array}$ & $\begin{array}{l}\text { CTTAGGACGCTCTTCGGGTACA } \\
\text { CTGCTCTCCAACCGACGACT }\end{array}$ & $474 \mathrm{bp}$ & Abou-Ghanem et al. (1997) \\
\hline
\end{tabular}


$39^{\circ} \mathrm{C}$ for $1 \mathrm{~h}$ and at $70^{\circ} \mathrm{C}$ for $10 \mathrm{~min}$. Virus specific band's amplification was done by adding to the synthesized cDNA $2.5 \mu \mathrm{l}$ of $10 \times$ Taq polymerase buffer, $1.5 \mathrm{mM}$ as final concentration of $\mathrm{MgCl}_{2}, 0.5 \mu \mathrm{l}$ of $10 \mathrm{mM}$ dNTPs, $0.5 \mu \mathrm{l}$ of 10 $\mu \mathrm{M}$ sense and antisense of each specific primer (Table 1), and $0.2 \mu \mathrm{l}$ of Taq polymerase ( 5 units $/ \mu \mathrm{l}$ ) in a final volume of $25 \mu$ l.

Amplification was carried out in a thermocycler (Thermo Fisher company, Waltham, Massachusetts, USA) after preliminary denaturation at $94^{\circ} \mathrm{C}$ for $5 \mathrm{~min}$, followed by 35 cycles at $94^{\circ} \mathrm{C}$ for $35 \mathrm{~s}$, annealing at $52^{\circ} \mathrm{C}$ for $45 \mathrm{~s}\left(54^{\circ} \mathrm{C}\right.$ for GLRaV-3) and $72^{\circ} \mathrm{C}$ for $1 \mathrm{~min}$, and a final extension step at $72^{\circ} \mathrm{C}$ for $7 \mathrm{~min}$. Amplified products were analyzed by electrophoresis in $1.2 \%$ agarose gel in $1 \mathrm{X}$ TBE buffer, then stained with ethidium bromide and visualized under UV illumination.

\section{Results}

Production of sanitized and vigorous somaplants us- ing somatic embryos induction. The typical procedure to initiate direct somatic embryos, which was used to produce somaplants, is illustrated in Fig. 1. Initiation of direct somatic embryo formation was generated on the cut edges and filaments surfaces, when cultured on modified $\mathrm{CP}$ enriched with $2 \mathrm{mg}^{-1}$ 2,4-D and $2.5 \mathrm{mg}^{-1} \mathrm{TDZ}$, as employed by Bouamama et al $(2007,2009)$. To inhibit any callus formation, our cultures were exposed to luminosity since culture initiation. Initially, the explants developed smooth nodular outgrowths on the adaxial surface, during the first week of culture initiation, whereas, on the proximal side, the anthers did not undergo any morphological remodeling (Fig. 1A). The nodular outgrowths are also observed on the two ends of the filament, when the anther is absent (Fig. 1B). On the other hand, the embryogenic state of the newly developed structures was observed and confirmed through ESEM analysis. In fact, the ESEM micrographies confirmed the direct formation of proembryos, which occurred at the cut edges of the filaments, precisely, from the epidermis (Fig. 1C, D).
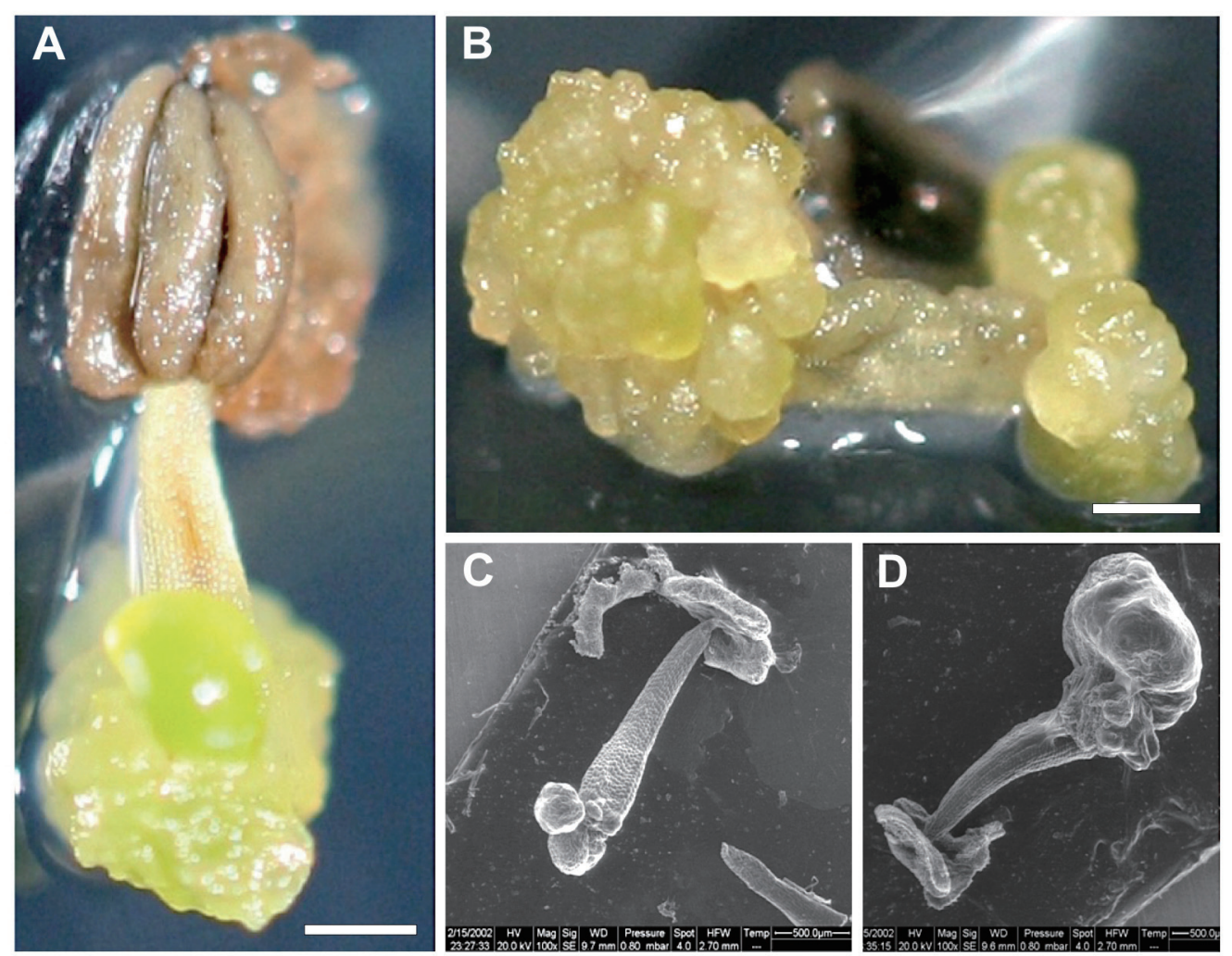

Fig. 1. Initiation of direct somatic embryogenesis. (A) Proembryogenic entities derived from the cut edge of filaments after two weeks of culture at $16 \mathrm{~h}$ of photoperiod $(\mathrm{G} \times 25)$. Bar represent $=1 \mathrm{~mm}$. (B) Proembryos derived from both abaxial and adaxial sides of the filaments $(\mathrm{G} \times 25)$. Bar represent $=1 \mathrm{~mm}$. $(\mathrm{C})$ Environmental scanning electron micrographs of the whole male floral organ of cv.'Hencha'. Note the development of somatic proembryos directly at the basal end of the filament. (D) Environmental scanning electron micrographs of the whole male floral organ (stamen) of cv.'Hencha'. Note the presence of somatic embryos at early and late globular stages. In both micrographs, anthers are necrotic or non-responsive during the embryogenic process. 

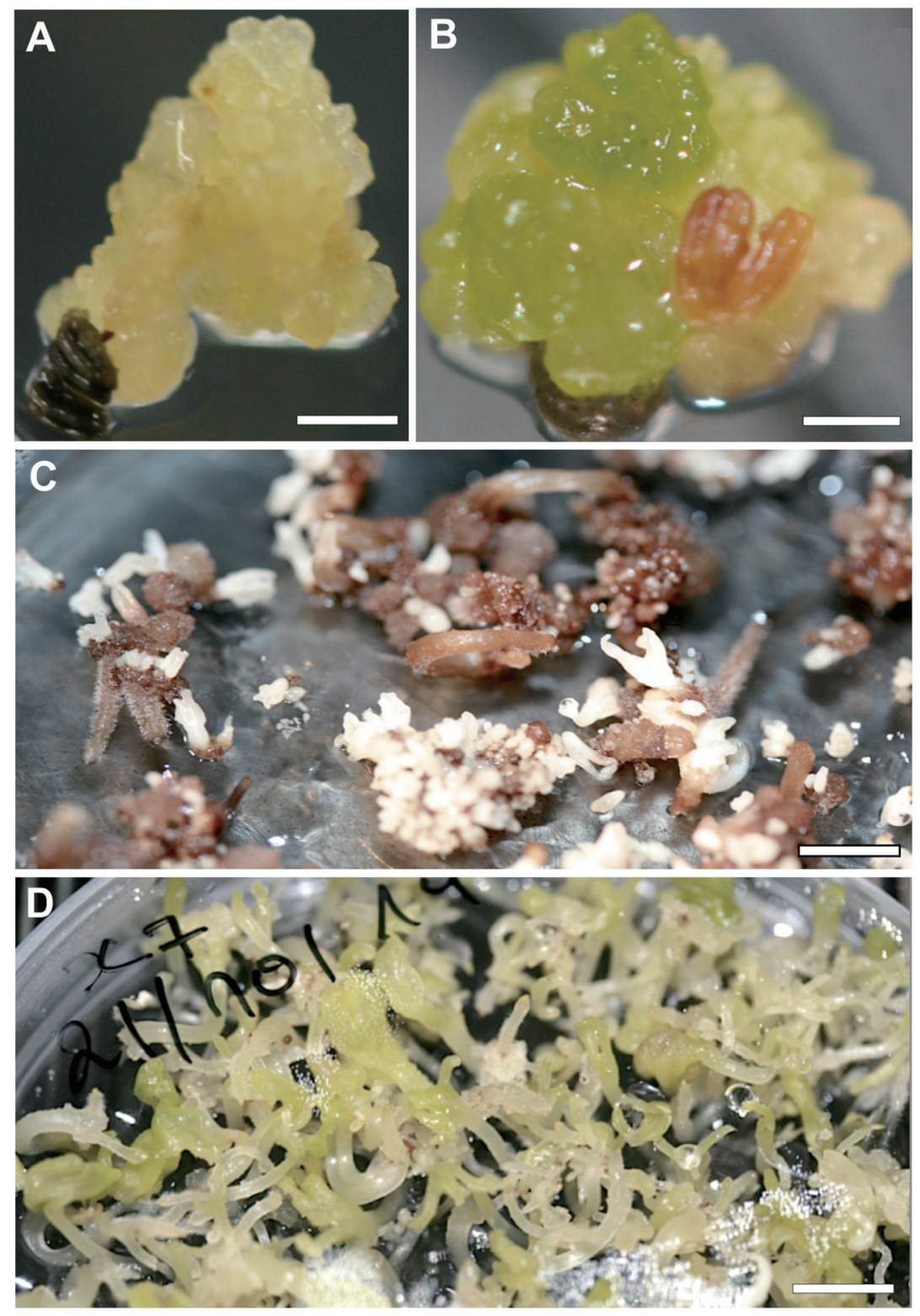

Fig. 2. Multiplication of 'Hencha' somatic embryos. (A) Somatic embryos reached the totality of the filament, when transferring explants to darkness. $(\mathrm{G} \times 10)$. Bar represent $=1 \mathrm{~mm}$. (B) Somatic embryos at globular and heart stages. $(\mathrm{G}$ $\times 10$ ). Bar represent $=1 \mathrm{~mm}$. (C) Intense proliferation of somatic embryos at cotyledonary stage elevated on primary and necrotic somatic embryos. $(G \times 4)$. Bar represent $=2 \mathrm{~mm}$. (D) Intense multiplication of greenish and germinated somatic embryos elevated on phytohormonefree MS basal medium enriched with charcoal $(\mathrm{G}$ $\times 4)$. Scale bar $=2 \mathrm{~mm}$.
Observations under stereomicroscope revealed that proembryos continue their multiplication through a secondary somatic embryogenesis. The recurrent embryos reached all the filaments, when the embryogenic cultures were transferred to complete darkness (Fig. 2A, B). After 18 weeks of culture, the proembryos developed and passed through globular, heart, torpedo-shaped stages and complete structural bipolar embryos (Fig. 2C). The germinated somatic embryos were produced in a large amount, when cultured on MS medium enriched with charcoal (Fig. 2D).

To perform conversion step, each germinated somatic embryos was cultivated separately on MS medium (Fig. $3 \mathrm{~A})$. For further growth, developing somaplantlets were removed from sterile culture conditions (Fig. 3B), acclima- tized and transferred to pots containing sterilized peat (Fig. 3C). The somaplantlets were carefully transferred in an insect proof, to minimize the risk of eventual re-contaminants. Somatic embryos derived from filaments of stamens gave rise to vigorous growing somaplants displaying the normal morphological characteristics of 'Hencha' grapevine (Fig. 3D).

Confirmation of the sanitary status of cv. 'Hencha' mother plant and progenitors by RT-PCR analysis. The sanitary status of the mother plant was carried out by ELISA assays. Among the 7 tested viruses (GFLV, GLRaV-1, GLRaV-2, GLRaV-3, ArMV, GFkV, GVA), ELISA assays indicated that 'Hencha' mother plant present a mixed 

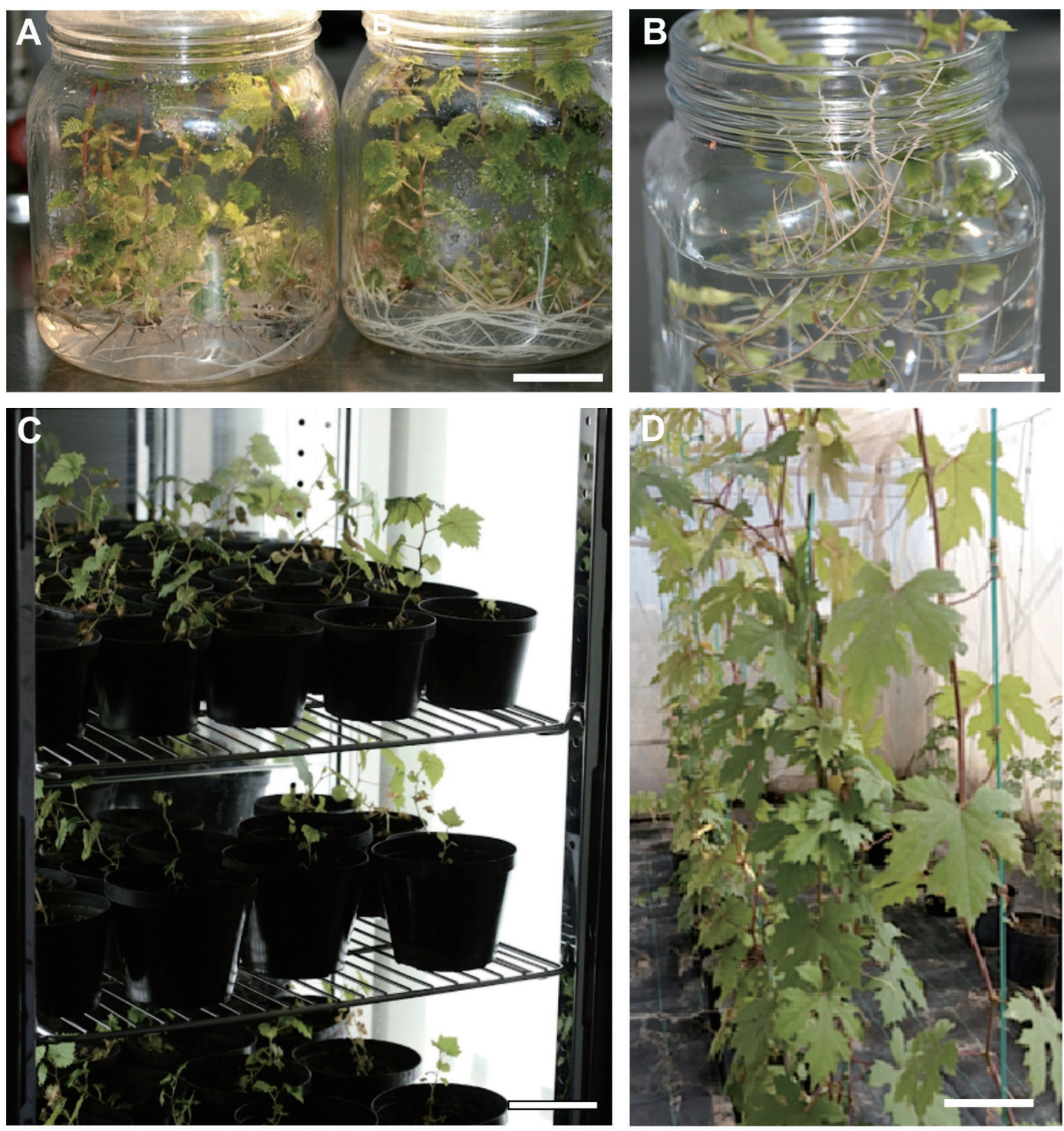

Fig. 3. Somaplants generated by direct somatic embryogenesis. (A) Conversion of germinated somatic embryos to rooted somaplantlets. Bar represent $=3 \mathrm{~cm}$. (B, C) Transfer of somaplants from sterile conditions and their maintenance in growth chamber (phytotron) with controlled parameters during 6 months. B. Bar represent $=3 \mathrm{~cm}$; C Scale bar $=3 \mathrm{~cm}$. (D) Somaplants growing vigorously in an insect proof. Bar represent $=3 \mathrm{~cm}$.

infection with GLRa-V-3 and GVA. In addition, molecular assays using RT-PCR confirmed the presence of GLRaV-3 and GVA, and showed the presence of GRSPaV as well as the absence of GVD in the mother plant (Fig. 4).

All regenerated somaplantlets were checked only for the presence of GVA, GLRaV-3 and GRSPaV viruses, 6 months after their acclimatization. As indicated in figure 4, which is a representative RT-PCR result, the RT-PCR disclosed that all regenerated somaplantlets were free from GVA, GRSPaV and GLRaV-3.
Ampelographic comparison between somaplants and 'Hencha' mother plant. After 2 years, all acclimatized somaplants were also checked for the conformity using ampelography analysis. Phenotypic characterization involving ampelographic description was applied on 50 'Hencha' somaclones for eight foliar descriptors (Table 2). The comparison of ampelographic data between the somaclones and the mother plant showed identical characteristics and a complete uniformity in 46 somaclones, except for somaclones H20, H21, H24 and H37, this corresponds to a per- 

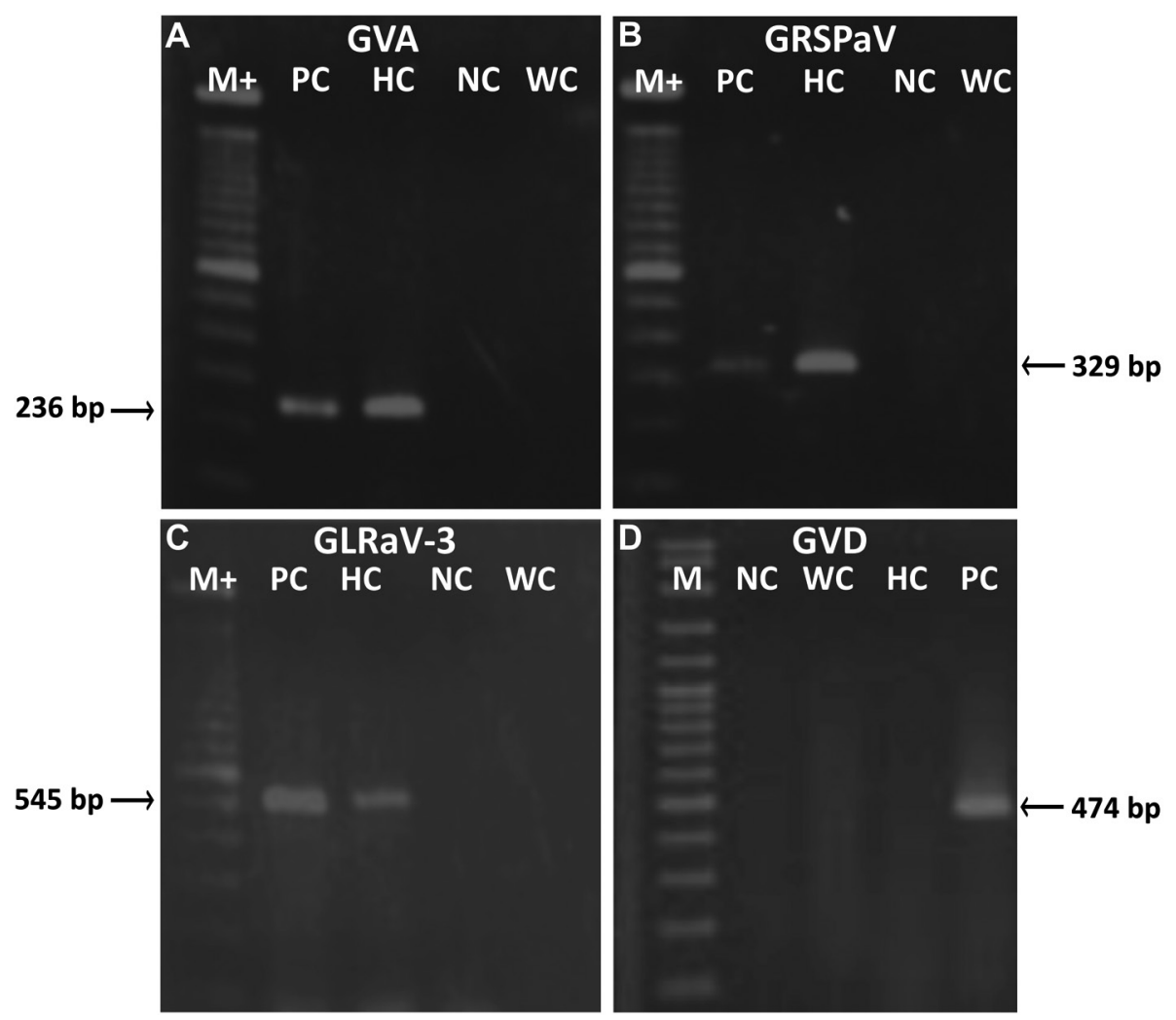

Fig. 4. Agarose gel (1.2\%) of RTPCR products amplified with specific primers. (A) GVA. (B) GRSPaV. (C) GLRaV-3. (D) GVD. M+ (Marker 100 bp+); M (Marker 100 bp); PC (Positive control); HM (Hencha Mother plant); HR (Hencha regenerated somaplantlet); NC (Negative control).

centage of off-type plants equal to $8 \%$.

According to the OIV descriptors, true-to-type vines 'Hencha' and progenitors showed identical characteristics in shoot tip. The length of the tendrils was short and the same at 'Hencha' and progenitors, between 12 and $15 \mathrm{~cm}$, density of prostrate hairs between main veins on lower side of blade is absent. Young leaves were green with bronzed spots. Parent and progenitors have the same, pentagonal, five lobed, straight and convex teeth present on both sides. The general shape of the petiole sinus is mid-open.

In somaclones H20, H23, H24 and H37, morphological differences related mainly to the mature leaves were observed, while complete uniformity was found for the descriptors in young shoots and young leaves (Table 2). Somaclones H20 and H24 differed from the 46 others somaclones in terms of blade shape and number of lobes; cuneiform vs. pentagonal shape (OIV 067), three lobes vs. five lobes (OIV 068). Somaclone H23 differed from somaclones $\mathrm{H} 20$ and $\mathrm{H} 21$ in term of blade shape cuneiform vs. pentagonal shape (OIV 067). Mature leaf character of somaclone $\mathrm{H} 37$ provided discriminative data (shape of blade and shape of teeth), convex vs. straight teeth (OIV 076), while the base of the petiole sinus was V-shaped vs. U-shaped (OIV 080).

\section{Discussions}

Several virus diseases against which control methods are not available have endangered grapevine production. The use of healthy propagating material is therefore important and necessary to prevent disease propagation. The cultivar 'Hencha' is a white native cultivar originated from the south of Tunisia, appearing to be a very promising cultivar for table and wine because of the interesting organoleptic characteristic of the fruit (Zemni, 2009), therefore it was selected for the sanitation program. As indicated in our serological results and confirmed by RT-PCR, 'Hencha' cultivar present a mixed infection with GVA, GLRa-V-3 and GRSPaV. The sanitary status of 'Hencha' as one cultivar among more than 60 other autochthonous grapevine belonging to the Center of Biotechnology of Borj-Cédria collection (Zoghlami et al., 2009), confirmed the impact of harmfulness of grapevine viruses and their effect on growth and fertility of Tunisian grapevine, as it was already determined (Mahfoudhi et al., 2008, 2014a, 2014b). In fact, Tunisia is a country with a warm climate, where the infection with the most important grapevine viruses, including those associated with degeneration, leafroll, rugose wood and fleck grapevine diseases, can be lethal within few years 
Table 2. Ampelographic description by Organisation Internationale de la Vigne et du Vin (OIV, 2007) modal values

\begin{tabular}{|c|c|c|c|c|c|c|c|c|}
\hline $\begin{array}{l}\text { D } \\
\text { S }\end{array}$ & $\begin{array}{c}\text { [O-016, U-16] } \\
\text { Shoot: (a) }\end{array}$ & $\begin{array}{l}\text { [O-017, U-17] } \\
\text { Shoot: length of } \\
\text { tendrils }\end{array}$ & $\begin{array}{l}\text { [O-051, U-7] } \\
\text { Young leaf: } \\
\text { (b) }\end{array}$ & $\begin{array}{l}{[\mathrm{O}-053, \mathrm{U}-8]} \\
\text { Young leaf: } \\
\text { (c) }\end{array}$ & $\begin{array}{l}\text { [O-067, U-20] } \\
\text { Mature leaf: } \\
\text { (d) }\end{array}$ & $\begin{array}{c}\text { [O-68, U-21] } \\
\text { Mature leaf: } \\
\text { (e) }\end{array}$ & $\begin{array}{c}\text { [O-076, U-26] } \\
\text { Mature leaf } \\
\text { (f) }\end{array}$ & $\begin{array}{l}\text { [O-079, U-27] } \\
\text { Mature leaf: } \\
\text { (g) }\end{array}$ \\
\hline H1 & 1 & 3 & 2 & 0 & 3 & 3 & 5 & 3 \\
\hline $\mathrm{H} 2$ & 1 & 3 & 2 & 0 & 3 & 3 & 5 & 3 \\
\hline H3 & 1 & 3 & 2 & 0 & 3 & 3 & 5 & 3 \\
\hline H4 & 1 & 3 & 2 & 0 & 3 & 3 & 5 & 3 \\
\hline H5 & 1 & 3 & 2 & 0 & 3 & 3 & 5 & 3 \\
\hline H6 & 1 & 3 & 2 & 0 & 3 & 3 & 5 & 3 \\
\hline H7 & 1 & 3 & 2 & 0 & 3 & 3 & 5 & 3 \\
\hline H8 & 1 & 3 & 2 & 0 & 3 & 3 & 5 & 3 \\
\hline H9 & 1 & 3 & 2 & 0 & 3 & 3 & 5 & 3 \\
\hline $\mathrm{H} 10$ & 1 & 3 & 2 & 0 & 3 & 3 & 5 & 3 \\
\hline H11 & 1 & 3 & 2 & 0 & 3 & 3 & 5 & 3 \\
\hline H12 & 1 & 3 & 2 & 0 & 3 & 3 & 5 & 3 \\
\hline H13 & 1 & 3 & 2 & 0 & 3 & 3 & 5 & 3 \\
\hline H14 & 1 & 3 & 2 & 0 & 3 & 3 & 5 & 3 \\
\hline H15 & 1 & 3 & 2 & 0 & 3 & 3 & 5 & 3 \\
\hline H16 & 1 & 3 & 2 & 0 & 3 & 3 & 5 & 3 \\
\hline H17 & 1 & 3 & 2 & 0 & 3 & 3 & 5 & 3 \\
\hline H18 & 1 & 3 & 2 & 0 & 3 & 3 & 5 & 3 \\
\hline H19 & 1 & 3 & 2 & 0 & 3 & 3 & 5 & 3 \\
\hline H20 & 1 & 3 & 2 & 0 & 2 & 2 & 5 & 3 \\
\hline H21 & 1 & 3 & 2 & 0 & 3 & 3 & 5 & 3 \\
\hline $\mathrm{H} 22$ & 1 & 3 & 2 & 0 & 3 & 3 & 5 & 3 \\
\hline $\mathrm{H} 23$ & 1 & 3 & 2 & 0 & 2 & 3 & 5 & 3 \\
\hline H24 & 1 & 3 & 2 & 0 & 2 & 2 & 5 & 3 \\
\hline $\mathrm{H} 25$ & 1 & 3 & 2 & 0 & 3 & 3 & 5 & 3 \\
\hline H26 & 1 & 3 & 2 & 0 & 3 & 3 & 5 & 3 \\
\hline H27 & 1 & 3 & 2 & 0 & 3 & 3 & 5 & 3 \\
\hline $\mathrm{H} 28$ & 1 & 3 & 2 & 0 & 3 & 3 & 5 & 3 \\
\hline H29 & 1 & 3 & 2 & 0 & 3 & 3 & 5 & 3 \\
\hline H30 & 1 & 3 & 2 & 0 & 3 & 3 & 5 & 3 \\
\hline H31 & 1 & 3 & 2 & 0 & 3 & 3 & 5 & 3 \\
\hline H32 & 1 & 3 & 2 & 0 & 3 & 3 & 5 & 3 \\
\hline H33 & 1 & 3 & 2 & 0 & 3 & 3 & 5 & 3 \\
\hline H34 & 1 & 3 & 2 & 0 & 3 & 3 & 5 & 3 \\
\hline H35 & 1 & 3 & 2 & 0 & 3 & 3 & 5 & 3 \\
\hline H36 & 1 & 3 & 2 & 0 & 3 & 3 & 5 & 3 \\
\hline H37 & 1 & 3 & 2 & 0 & 2 & 3 & 4 & 3 \\
\hline H38 & 1 & 3 & 2 & 0 & 3 & 3 & 5 & 3 \\
\hline H39 & 1 & 3 & 2 & 0 & 3 & 3 & 5 & 3 \\
\hline H40 & 1 & 3 & 2 & 0 & 3 & 3 & 5 & 3 \\
\hline H41 & 1 & 3 & 2 & 0 & 3 & 3 & 5 & 3 \\
\hline H42 & 1 & 3 & 2 & 0 & 3 & 3 & 5 & 3 \\
\hline H43 & 1 & 3 & 2 & 0 & 3 & 3 & 5 & 3 \\
\hline H44 & 1 & 3 & 2 & 0 & 3 & 3 & 5 & 3 \\
\hline H45 & 1 & 3 & 2 & 0 & 3 & 3 & 5 & 3 \\
\hline H46 & 1 & 3 & 2 & 0 & 3 & 3 & 5 & 3 \\
\hline H47 & 1 & 3 & 2 & 0 & 3 & 3 & 5 & 3 \\
\hline H48 & 1 & 3 & 2 & 0 & 3 & 3 & 5 & 3 \\
\hline H49 & 1 & 3 & 2 & 0 & 3 & 3 & 5 & 3 \\
\hline H50 & 1 & 3 & 2 & 0 & 3 & 3 & 5 & 3 \\
\hline MP & 1 & 3 & 2 & 0 & 3 & 3 & 5 & 3 \\
\hline
\end{tabular}

Three observations were performed for each 'Hencha' somaclone.

Abbreviations: (a) number of consecutive tendrils. (b) color of upper side of blade (fourth leaf). (c) density of prostrate hairs between main veins on lower side of blade (fourth leaf). (d) shape of blade. (e) number of lobes. (f) number of teeth. (g) degree of opening/overlapping of petiole sinus. D: descriptors. S: somaclones. MP: Hencha mother plant. 
(Mahfoudhi et al., 1998).

The use of healthy propagating material is an important measure for the control of grapevine viruses, and sanitation is the only way to generate virus-free somaclones to be included in a certification program. In this study, we evaluated the pathway of direct somatic embryogenesis by filaments cultures of stamen for the elimination of a mixed infection with a Vitivirus (GVA), an Ampelovirus (GL$\mathrm{RaV}-3$ ), and a Foveavirus (GRSPaV) from a local grapevine cultivar.

In fact, the GRSPaV seems to be the most common disease of the rugose wood complex. In their study, Meng et al. (2005) reported that GRSPaV alone induces few or no rugose wood symptoms and some of its strains are latent in Vitis rupestris. While, the presence of GRSPaV together with other viruses can cause severe damage to infected grapevine plants as indicated by Gribaudo et al (2006). Furthermore, the rugose wood damage is more evident in warmer climate; such is the case in Tunisia. That is why the mixed infection, with GVA, GLRaV-3, and GRSPaV, can be lethal for 'Hencha' cv., hence the importance to eradicate the three viruses. As reported in grapevine culture, every virus infection has some effect on growth and quality, especially in long-term cultures as grapevine. In their study on grapevine, Al Rwahnih et al. (2015) deduced that simultaneous infection by multiple viruses could significantly increase severity of symptoms.

On the other hand, the findings of the present study revealed that filament, as a sexual male organ, is fairly good source for a direct and recurrent somatic embryogenesis induction. In addition, the totalities of somatic embryos obtained directly from filament are virus-free. By the same manner, somatic embryogenesis using floral organs is also very effective in virus and viroids elimination in other plant species such as citrus (Meziane et al., 2017). Similar results were obtained in cassava (Nkaa et al., 2013) and cocoa (Edward and Wetten, 2016; Quainoo et al., 2008).

It is well known that the distribution of viruses in infected plants is uneven. In fact the meristematic dome generally either free or contain a very low virus titer (Helliot et al., 2002). However, the presence of certain virus particles, such as GRSPaV, in the pollen and its transmission through seeds has been experimentally demonstrated (Lima et al., 2006). Other viruses such as nepovirus, ampelovirus and closterovirus are restricted to vascular tissues. In general, it seems that a success of a virus elimination method depends on grapevine genotype, but also on virus species and the specific virus-genotype interactions (Maliogka et al., 2009). In ESEM analysis and regarding the ontogeny of grapevine somatic embryos, we confirmed that proembryos proliferate into mature somatic embryos without any callus production. Furthermore, somatic embryos are clearly visualized as bipolar and autonomous entities in ESEM figures. We demonstrate that there is no vascular connection between two neighboring embryos or between embryos and mother tissue. Our results were supported previously by the findings of Goussard et al. (1991), which demonstrated that leafroll associated viruses are absent in both regenerated embryos and plantlets. These authors also indicate that there was no translocation of these viruses from infected tissue via proliferating callus to somatic embryos. Recurrent somatic embryogenesis is considered as the reason for the sanitation of 'Hencha' cultivar. In addition, we have evidence that 'Hencha' regenerated somatic embryos are sanitized, because GVA, GRSPaV and GLRaV-3 are restricted to vascular tissue or are phloem-limited viruses.

On the other hand, Quainoo et al. (2008) demonstrated, that cocoa somatic embryogenesis was capable of the progressive interruption of the movement of cocoa swollen shoot virus (CSSV) of infected cocoa trees, from primary somatic embryos to secondary somatic embryos. In fact, through qualitative and quantitative screening of the virus, the authors confirmed that callus tissues recorded high viral infection. They also confirmed that CSSV is capable of movement from the callus tissues into primary somatic embryos, but at a reduced frequency. To determine absolute CSSV levels during the somatic embryogenesis process, the authors demonstrated that 23 out of 24 secondary somatic embryos exhibited no virus copies per cell. The findings of Quainoo et al. (2008) justified our choice for a recurrent somatic embryogenesis.

The present report is the first to show effective elimination of GLRaV-3, GVA, and GRSPaV, when direct and recurrent somatic embryogenesis was induced directly from filament of stamen culture. We demonstrated that direct and recurrent somatic embryos induction was successfully used in the elimination of the mixed infection in $100 \%$ of the regenerated somaclones. These results were consistently confirmed by all the RT-PCR assays conducted in ex-vitro conditions. The first descriptions and other information of 61 locale Tunisian cultivars were provided by Lamine et al (2014). However, in this study, the use of some foliar descriptors is also considered the first work dealing with the homology degree between Hencha cultivar and their 50 progenitors, six months after acclimatation. Further OIV descriptors, such as floral, shoot and berries will be investigated when somaplantlets will reach maturity.

To conclude, this is the first report that describes the use of direct somatic embryogenesis for virus elimination of a Tunisian autochthonous grapevine. We confirmed, through 
this study that filaments of stamens cultured on CP basedmedium enriched with 2,4-D and TDZ has the advantage to develop direct somatic embryos followed by secondary somatic embryos without any callus phase. This procedure reduces somaclonal variation event and permit to develop in a short time healthy grapevine somaplant. In fact, $92 \%$ of regenerated somaplants were morphologically uniform. The developed method appears to be suitable for the application of this in vitro process to other endangered local grapevine cultivars, because of diseases. In addition the virus-free 'Hencha' somaplants preserved in the insect proof permit to the ampelographer to built up rigorous ampelographic and ampelometric data matrices for endangered native local grapevines. In addition, virus-free material is necessary for evaluating germaplasm potentialities.

Ampelographic investigations will be supported, in a future work, by molecular marker analysis to reevaluate the progenitors of grapevine 'Hencha' cultivar.

\section{Acknowledgments}

This work was financially supported by the European Union in the framework of the Tuniso-italian project "Développement des Interventions innovantes sur les cépages de Vignes autochtones pour l'Intégration italotunisienne" Grant number: DIVIN- PS 1.1.002.

\section{References}

Abou-Ghanem, N., Saldarelli, P., Minafra, A., Buzkan, N., Castellano, M. A. and Martelli, G. P. 1997. Properties of grapevine virus D, a novel putative Trichovirus. J. Plant Pathol. 78:1525.

Al Rwahnih, M., Daubert, S., Golino, D., Islas, C. and Rowhani, A. 2015. Comparison of next generation sequencing versus biological indexing for the optimal detection of viral pathogens in grapevine. Phytopathology 105:758-763.

Baggiolini, M. 1952. Phenological stages in the annual development of grapevines and their practical use. Rev. Rom. Agr. Vit. Arb. 8:4-6.

Bouamama, B., Ben Salem-Fnayou, A., Ben Jouira, H., Ghorbel, A. and Mliki, A. 2007. Influence of the flower stage and culture medium on the induction of somatic embryogenesis from anther culture in Tunisian grapevine cultivars. J. Int. Sci. Vigne Vin 41:185-192.

Bouamama, B., Jardak, R., Ben Salem-Fnayou, A., Ghorbel, A. and Mliki, A. 2009. Preservation of endangered Tunisian grapevine cultivars using embryogenic cultures. Electron. J. Biotechnol. 12. doi: 10.2225/vol12-issue2-fulltext-3/.

Bouamama, B., Ben Salem, A., Zoghlami, N., Zemni, H., Mliki, A. and Ghorbel, A. 2011. Somatic embryogenesis and plantlet regeneration from immature anthers in Opuntia ficus-indica. $J$.
Hortic. Sci. Biotechnol. 86:313-318.

Chée, R. and Pool, R. M. 1987. Improved inorganic media constituents for in vitro shoot multiplication of Vitis. Sci. Hortic. 32:85-95.

Edwards, R. and Wetten, A. 2016. Virus Detection and Elimination in Cocoa (Theobroma cacao L.) Through Somatic Embryogenesis. J. Plant Sci. 4:52-57.

Foissac, X., Svanella-Dumas, L., Gentit, P., Dulucq, M. J. and Candresse, T. 2001. Polyvalent detection of fruit tree Trico, Capillo and Foveaviruses by nested RT-PCR using degenerate and inosine containing primers (DOP RT-PCR). Acta Hort. 550:37-43.

Goussard, P. G., Wiid, J. and Kasdorf, G. G. F. 1991. The effectiveness of in vitro somatic embryogenesis in eliminating fanleaf virus and leafroll associated viruses from grapevines. S. Afr. J. Enol. Vitic. 12:77-81.

Goussard, P. G. and Wiid, J. 1992. The elimination of fanleaf virus from grapevines using in vitro somatic embryogenesis combined with heat therapy. S. Afr. J. Enol. Vitic. 13:81-83.

Gribaudo, I., Gambino, G., Cuozzo, D. and Mannini, F. 2006. Attempts to eliminate Grapevine rupestris stem pitting-associated virus from grapevine clones. J. Plant Pathol. 88:293-298.

Gugerli, P. 2003. Grapevine leafroll and related viruses. In: Extended abstracts 14th meeting of ICVG, pp. 25-31. Locorotondo, Italy.

Helliot, B., Panis, B., Poumay, Y., Swenen, R., Lepoivre, P. and Frison, E. 2002. Cryopreservation for the elimination of cucumber mosaic and banana streak viruses from banana (Musa spp.) Plant Cell Rep. 20:1117-1122.

Lamine, M., Zemni, H., Ziadi, S., Chabaane, A., Melki, I., Mejri, S. and Zoghlami N. 2014. Multivariate analysis and clustering reveal high morphological diversity in Tunisian autochthonous grapes (Vitis vinifera): insights into characterization, conservation and commercialization. J. Int. Sci. Vigne Vin 48:111-122.

Lima, M. F., Alkowni, R., Uyemoto, J. K., Golino, D. A., Osman, F. and Rowhani, A. 2006. Molecular analysis of a California strain of Rupestris stem pitting-associated virus isolated from declining Syrah grapevines. Arch. Virol. 151:1889-1894.

Ling, K. S., Zhu, H. Y., Drong, R. F., Slightom, J. L., McFerson, J. R. and Gonsalves, D. 1998. Nucleotide sequence of the 3'-terminal two-thirds of the Grapevine leafroll-associated virus-3 genome reveals a typical monopartite closterovirus. $J$. Gen. Virol. 79:1299-1307.

Mackenzie, D. J. 1997. A standard protocol for the detection of viruses and viroids using a reverse transcription-polymerase chain reaction technique. Document CPHBT-RT-PCR1.00. The Canadian Food Inspection Agency.

Mahfoudhi, N., Digiaro, M., Savino, V. and Di Terlizzi, B. 1998. Viruses and virus diseases of grapevine in Tunisia. Bull. OEPP 28:197-204.

Mahfoudhi, N., Digiaro, M. and Dhouibi, M. H. 2008. Incidence and distribution of Grapevine leafroll-associated viruses in Tunisian vineyards. J. Phytopathol. 156:556-558. 
Mahfoudhi, N., Habili, N., Masri, S. Q. and Dhouibi, M. H. 2007. First report on the occurrence of Grapevine leafroll-associated viruses 5 and 9 in Tunisian grapevines. Plant Dis. 91:1359.

Mahfoudhi, N., Soltani, I., Digiaro, M. and Elbeaino, T. 2014a. Occurrence and widespread distribution of grapevine virus D in Tunisian grapevines. J. Plant Pathol. 96:431-439.

Mahfoudhi, N., Harbi-Ben Slimane, M., Elair, M., Selmi, I. and Ben Hamda, H. 2014b. Prevalence of viruses infecting autochthonous grapevines in Tunisia. Tunis. J. Plant Prot. 9:111-118.

Maliogka, V. I., Skiada, F. G., Eleftheriou, E. P. and Katis, N. I. 2009. Elimination of a new ampelovirus (GLRaV-Pr) and Grapevine rupestris stem pitting associated virus (GRSPaV) from two Vitis vinifera cultivars combining in vitro thermotherapy with shoot tip culture. Sci. Hortic. 123:280-282.

Martelli, G. P., Sabanadzovic, S., Abou-Ghanem-Sabanadzovic, N., Edwards, M. C. and Dreher, T. 2002. The family Tymoviridae. Arch. Virol. 147:1837-1846.

Martelli, G. P. 2009. Grapevine virology highlights. In: Extended abstracts of the 16th meeting of ICVG, pp. 15-24. Dijon, France.

Martelli, G. P. 2014. Directory of virus and virus-like diseases of the grapevine and their agents. J. Plant Pathol. 96:1-136.

Meng, B., Li, C., Wang, W., Goszczynski, D. and Gonsalves, D. 2005. Complete genome sequences of two new variants of Grapevine rupestris stem pitting-associated virus and comparative analyses. J. Gen. Virol. 86:1555-1560.

Meziane, M., Frasheri, D., Carra, A., Boudjeniba, M., D’onghia, A. M., Mercati, F., Djelouah, K. and Carimi, F. 2017. Attempts to eradicate graft-transmissible infections through somatic embryogenesis in Citrus ssp. and analysis of genetic stability of regenerated plants. Eur. J. Plant Pathol. 148:8595.

Murashige, T. and Skoog, F. 1962. A revised medium for rapid growth and bio assays with Tobacco tissue cultures. Physiol. Plant. 15:473-497.

Nkaa, F. A., Ene-Obong, E. E., Taylor, N., Fauquet, C. and Mbanaso E. N. A. 2013. Elimination of African Cassava
Mosaic Virus (ACMV) and East African Cassava Mosaic Virus (EACMV) from cassava (Manihot esculenta Crantz) cv. 'Nwugo' via somatic embryogenesis. Am. J. Biotechnol. Mol. Sci. 3:33-40.

OIV. 2007. 2nd Edition of the OIV descriptors list for grape varieties and Vitis species. Paris, France. 233 pp.

OIV. 2016. OIV statistical report on world vitiviniculture. $16 \mathrm{pp}$.

Quainoo, A. K., Wetten, A. C. and Allainguillaume, J. 2008. The effectiveness of somatic embryogenesis in eliminating the cocoa swollen shoot virus from infected cocoa trees. J. Virol. Methods 149:91-96.

Saldarelli, P. 2012. Rugose wood-associated viruses and similia: 2010-2012. In: Proceedings 17th congress of ICVG, pp. 7881. Davis, USA.

Santini, D., Rolle, L. and Mannini, F. 2009. Control of grape berry mechanical properties modifications due to GFLV by mean of texture analysis. In: Extended abstracts of the 16th Meeting of ICVG, pp. 258-259. Dijon, France.

Uyemoto, J. K. and Rowhani, A. 2003. Discovery of different grapevine sources with graft-transmissible agents causing union-incompatibility on sensitive rootstocks. In: Extended abstracts of the 14th ICVG Conference, pp. 139-140. Locorotondo, Italy.

Waite, H., Whitelaw-Weckerta, M. and Torleya, P. 2015. Grapevine propagation: principles and methods for the production of high-quality grapevine planting material. N. Z. J. Crop Hortic. Sci. 43:144-161.

Zemni, H. 2009. Caractérisation organoléptique et pomologique et quelques variétés de vignes autochtones tunisiennes. Thèse de Doctorat, Faculté des Sciences de Tunis, El Manar. 178 pp.

Zoghlami, N., Mliki, A. and Ghorbel, A. 2001. Evaluation of genetic diversity among Tunisian grapevines by RAPD markers. Vitis 40:31-37.

Zoghlami, N., Riahi, L., Laucou, V., Lacombe, T., Mliki, A., Ghorbel, A. and This, P. 2009. Origin and genetic diversity of Tunisian grapes as revealed by microsatellite markers. Sci. Hortic. 120:479-486. 